\title{
Correction to: Prepayment and future cross-buying: an exploratory analysis
}

\author{
Shinhye $\mathrm{Kim}^{1}$ (D) Alberto Sa Vinhas ${ }^{2}$ - U. N. Umesh ${ }^{2}$ \\ Published online: 7 February 2022 \\ (c) Springer Science+Business Media, LLC, part of Springer Nature 2022
}

\section{Correction to: Marketing Letters \\ https://doi.org/10.1007/s11002-021-09610-7}

The copyright holder for this article was incorrectly given as 'This is a U.S. government work and not under copyright protection in the U.S.; foreign copyright protection may apply' but should have been 'The Author(s), under exclusive licence to Springer Science + Business Media, LLC, part of Springer Nature'.

Publisher's Note Springer Nature remains neutral with regard to jurisdictional claims in published maps and institutional affiliations.

The original article can be found online at https://doi.org/10.1007/s11002-021-09610-7.

\section{Shinhye Kim}

kimshin@missouri.edu

Alberto Sa Vinhas

asavinhas@wsu.edu

U. N. Umesh

umesh@wsu.edu

1 University of Missouri-Columbia, 700 Tiger Ave Cornell Hall, Columbia, MO 65211, USA

2 Washington State University, 14204 NE Salmon Creek Ave, Vancouver, WA 98686, USA 